To Maega | JurnalPengabdianMasyarakat

Oktober 2021, Vol.4, No.3, hal, 331-340

$\operatorname{ISSN}(P): 2622-6332 ; \operatorname{ISSN}(E): 2622-6340$

http://www.ojs.unanda.ac.id/index.php/tomaega

\title{
Pendampingan Usaha Produksi dan Pemasaran Pupuk Organik Cair (POC) Berbasis Urin Manusia Pada Kelompok Usaha Rajawali Desa Wunduwatu Kecamatan Andoolo Kabupaten Konawe Selatan
}

\author{
Abu Rahman', Melati ${ }^{2}$, Milawati Saranani ${ }^{3}$ \\ ${ }^{1}$ Agribisnis, Fakultas Pertanian, Universitas Lakidende Unaaha \\ 2 Manajemen, Fakultas Ekonomi dan Bisnis, Universitas Lakidende Unaaha \\ 3Agribisnis, Fakultas Pertanian, Universitas Lakidende Unaaha \\ *Correspondent Email: editadung@yahoo.com
}

Article History:

Received: 18-09-2021; Received in Revised: 07-10-2021; Accepted: 12-10-2021

DOI: http://dx.doi.org/10.35914/tomaega.v4i3.859

\begin{abstract}
Abstrak
Kelompok usaha POC Rajawali Desa Wunduwatu merupak kelompok usaha yang mengolah urin manusia dari warga sekitar sejak tahun 2017. Pengumpulan urin dilakukan dengan cara mengharapkan warga sekitar datang menukarkan urinnya dilokasi usaha ini. Kelompok Rajawali masih menggunakan cara-cara yang konvensional sederhana sehingga tahapan proses produksi belum optimal, demikian pula metode pemasaran masih dari mulut ke mulut warga. Tujuan pendampingan ini guna meningkatkan produktifitas POC dan meningkatkan keuntungan usaha melalui strategi pemasaran yang efektif. Metode pendampingan dilaksanakan melalui pelatihan selama 2 (dua) hari) pada aspek peningkatan produksi dengan metode pembuatan mikroba khusus campuran urin manusia, melalui dan pembuatan 200 buah wadah penyimpanan urin kapasitas 1 liter dan mengurangi waktu penghancuran sabuk kelapa (80\%). Pada kegiatan pelatihan teknologi produksi yakni mengurangi waktu produksi melalui penghancuran sabuk kelapa menggunakan mesin parut sabut kelapa. Selanjutnya dilakukan pendampingan modal produksi yakni inisiasi kerjasama donatur keuangan pengembangan modal kerjasama dengan Bank Bahteramas Provinsi Sulawesi Tenggara Cabang Unaaha. Sedangkan pada aspek pemasaran dilakukan pelatihan pendampingan promosi produk, menjajakan langsung produk didistributor/Toko pertanian, pasar tradisional walaupun penjualan dilakukan tidak resmi oleh karena produk ini belum mengantongi ijin edar. Hasil kegiatan pendampingan menunjukkan peningkatan produksi stok urin naik 200 liter/hari) atau naik 40\%, kemudian peningkatan produksi POC 600 liter/6 hari atau naik 25\% serta hasil kegiatan pendampingan pemasaran keuntungan usaha awalnya omset ini 4-5 juta/bulan setelah kegiatan pendampingan omset meningkat 9 juta/bulan. Hasil kegiatan pendampingan ini mampu pula mengurangi jumlah pengangguran disekitar lokasi mampu menyerap pekerja baru khususnya dari kalangan ibu rumah tangga..
\end{abstract}

Kata Kunci : Pendampingan, Pelatihan Produksi, Pemasaran, POC.

\section{Abstract}

The POC Rajawali business group in Wunduwatu Village is a business group that has been processing human urine from local residents since 2017. Urine collection is done by expecting local residents to exchange their urine at this business location. The Rajawali group still uses conventional methods so that the stages of the production process are not 
optimal, as well as marketing methods are still word of mouth. The purpose of this assistance is to increase POC productivity and increase profits through effective marketing strategies. The mentoring method is carried out through training for 2 (two) days on the aspect of increasing production with the method of making special microbes mixed with human urine, through and making 200 urine storage units with a capacity of 1 liter and reducing coconut belt time (80\%). In production technology activities, namely reducing production time through a coconut belt using a coconut grater machine. Furthermore, production capital assistance was carried out, namely the initiation of cooperation with donors for the development of cooperative capital with Bank Bahteramas, Southeast Sulawesi Province, Unaaha Branch. Meanwhile, in the marketing aspect, training on product promotion assistance is carried out, direct selling of products to agricultural distributors/shops, traditional markets even though sales are not official because this product has not yet obtained a distribution permit. The results of the activity show an increase in urine stock production (200 liters/day) or up 40\%, then an increase in POC production of 600 liters/6 days or an increase of $25 \%$ and the results of this initial marketing assistance activity turn out 4-5 million/month after the mentoring activity increased turnover. 9 million/month. The results of this mentoring activity were able to reduce the number of movements around the location and were able to absorb new workers, especially from housewives.

Keywords: Assistance, Production Training, Marketing, POC.

\section{Pendahuluan}

Setiap usaha pasti memiliki persoalan meskipun kecenderungan masalah yang dihadapi adalah sama atau mirip antara satu dengan yang lainnya namun selalu saja permasalahan tersebut memilki karakreriksik tersendiri. Seperti hal usaha kelompok pengolahan pupuk organik cair berbasis urin manusia yang diketuai oleh Bapak Rohsidin ini juga tidak luput dari berbagai masalah yang dihadapi. Faktor produksi yang dimaksud adalah berbagai macam input yang digunakan untuk melakukan proses produksi. Faktor-faktor produksi tersebut dapat diklasifikasi menjadi faktor produksi tenaga kerja, modal, dan bahan mentah (Apriyani \& Muhsin, 2017). Justifikasi pengusul bersama mitra yakni Permasalahan Pasokan Bahan Mentah. Sejak berdiri tahun 2017 lalu kelompok usaha ini menghasilkan 300-500 liter pupuk cair dalam kemasan jadi perbulannya. Sejauh ini stok urin masih didapatkan dari warga Desa Wunduwatu belum dilakukan perluasan pasokan bahan baku yang tersedia luas dan mudah didapatkan didesa-desa sekitarnya. Berdasarkan pengamatan potensial urin manusia didaerah Kabupaten Konawe selatan sangat besar, jika dimaksimalkan pengumpulannya maka stok bahan baku pembuatan ini akan melimpah. Seperti dikeluhkan oleh kelompok usaha ini bahwa stok urin yang didapatkan masih dalam jumlah kecil hal ini disebabkan oleh proses pengumpulan urin masih dilakukan dengan cara mengharapkan warga sendiri datang menukarkan urinnya dilokasi usaha ini (Wawancara Ketua kelompok Rajawali bapak Rohsidin).

Proses pembuatan pupuk organik cair (POC) tersebut masih menggunakan cara - cara yang konvensional sederhana sehingga beberapa bagian pada tahapan proses produksi belum sesuai harapan yang tentunya akan mempengaruhi produktifitas produk secara kuantitas. Contohnya proses (C) To Maega / JurnalPengabdian Masyarakat. This is an open access article under the CC BY-SA 4.0 license (https://creativecommons.org/licenses/by-sa/4.0/). 
penghancuran sabuk kelapa masih dilakukan menggunakan tenaga manusia, cukup memakan waktu. Demikin pula fasilitas produksi lainya yang kurang memadai. Pasalnya selama ini lokasi produksi pupuk cair ini berada dirumah ketua kelompok sehingga lahan terbatas dan peralatan masih seadanya saja.

Tidak dapat dipungkiri bahwa setiap usaha menginginkan biaya operasional yang seminimal mungkin dengan hasil yang semaksimal mungkin. Usaha kelompok ini pembuatan POC ini telah mempekerjakan beberapa warga sekitar ditambah tenaga harian dengan upah rata-rata 80.000 rupiah perhari, jumlah pekerja ini relatif cukup berdasarkanvolume pekerjaan yang dilakukan akan tetapi disisi yang lain upah pekerja cukup membebani biaya operasional usaha. Hal ini menjadi dilema oleh karena hasil penjualan produk ini atau keuntungannya sebagai satu-satunya sumber pembiayaan yang masih sering fluktuatif padahal disisi lain kegiatan operasional mesti tetap berjalan sebagai lapangan kerja baru yang cukup meningkatkan ekonomi khususnya para ibu rumah tangga sekitar.

Seperti yang telah disampaikan diawal bahwa keuntungan usaha ini dalam perbulan berkisar 4- 5 juta jika permintaan pasar meningkat. Artinya nominal tersebut masih kecil dapat ditingkatkan. Oleh karena itu strategi pemasaran yang tepat menjadi faktor penting dalam meningkatkan hasil penjualan yang besar (Sofjan, 2008). Hasil observasi dan justifikasi bersama mitra dilokasi terungkap persoalan spesifik usaha ini yaitu promosi adalah arus informasi atau persuasi satu arah yang dibuat untuk mengarahkan seseorang atau organisasi kepada tindakan yang menciptakan pertukaran pemasaran (Handoko, 2000).

Berdasarkan data menunjukan bahwa jumlah produksi POC ini setiap bulannya berkisar 300-500 liter. Angka penjualan belum maksimal disebabkan minimnya informasi produk ini ditengah masyarakat, pola pemasaran yang hanya mengandalkan informasi dari mulut ke mulut belum efektif, belum ada konsep saluran strategis pemasaran yang jelas (Wawancara, 2 Agustus 2021, Ketua Kelompok Rajawali), padahal informasi yang dimiliki lengkap tentang produk penjual, harga dan manfaat, semakin baik informasi yang dimiliki pembeli, semakin kuat pula posisi tawar menawarnya (Swastha \& Irawan, 2006). Sebuah produk menuntut usahawan mampu menetapkan manfaat-manfaat yang akan diperoleh konsumen. Manfaat tersebut hendaknya dipenuhi oleh atribut produk misalnya dalam bentuk legalitas, ciri produk, design dan kualitas produk (Irwan \& Haryono, 2015). Ciri produk menunjukkan hal kompetitif yang membedakan produk dengan produk pesaing, sedangkan design menunjukkan bahwa produk tersebut adalah produk yang simple, aman, sederhana dan ekonomis sehingga dirasakan kualitas dan manfaat bagi masyarakat (Philip, 2000) (Didiharyono, 2016).

Produk pupuk organik cair (POC) berbasis urin manusia produksi usaha Rajawali milik Bapak Roshidin belum memiliki izin edar. Produk ini belum mendapatkan branding dimasyarakat khususnya masyakat luar daerah Konawe CTo Maega / JurnalPengabdian Masyarakat. This is an open access article under the CC BY-SA 4.0 license (https://creativecommons.org/licenses/by-sa/4.0/). 
Selatan. Branding atau pembuatan merek adalah nyawa bagi sebuah produk yang akan atau telah dijual. Branding merupakan hal yang paling penting ketika membangun identitas. Sebuah merk mesti didesain dan dibangun untuk menyampaikan pesan dengan jelas, membangun kepercayaan dan kredibilitas usaha, mengikat pelanggan secara emosional, memotivasi pembeli, dan juga mengamankan loyalitas pembeli yang berdampak positif bagi nilai jual produk. Edukasi yang minim dikalangan masyarakat terhadap keuntungan menggunakan pupuk organik turut mempengaruhi nilai tawar produk dipasaran (Fred 2009).

\section{Metode}

Kegiatan Pelatihan dilakukan selama 2 hari pada tanggal 2-3 Agustus 2021 berlokasi di lokasi Mitra Kelompok Rajawali Desa Wunduwatu Kecamatan Andoolo Kabupaten Konawe Selatan

\subsection{Pelatihan Peningkatan Produksi}

1. Pelatihan dikuit oleh sejumlah anggota Kelompok Rajawali ini menghasilkan kemampuan mitra (kelompok Rajawali) dalam mengolah produk POC menjadi lebih efektif dan efisien dalam penggunaan bahan baku dan mampu mengurangi masa waktu kerja pengolahannya, Peningkatan Produksi POC 600 liter/ 6 hari.

2. Penyediaan Wadah Penampungan pasokan bahan mentah/urin. Penyediaan berupa jerigen 1 liter sebanyak 200 buah dirumah warga sekitar mitra. Luarannya adalah melalui wadah yang disiapkan mitra mampu mengumpulkan bahan baku urin sebanyak 500- 1000 liter urin dari warga. Pendampingan Membentuk Unit Pengolahan Pupuk Organik (UPPO).

3. Luaran dari kegiatan ini sebelum kegiatan keterampilan kelompok usaha POC Rajawali hanya dimiliki oleh ketua kelompok dari hasil pelatihan yang pernah diikuti setelah kegiatan seluruh tenaga kerja meningkat keterampilan produksinya. Sebelum kegiatan jumlah tenaga kerja 3 orang setelah dilaksanakan kegiatan pendampingan peningkatan jumlah produksi.

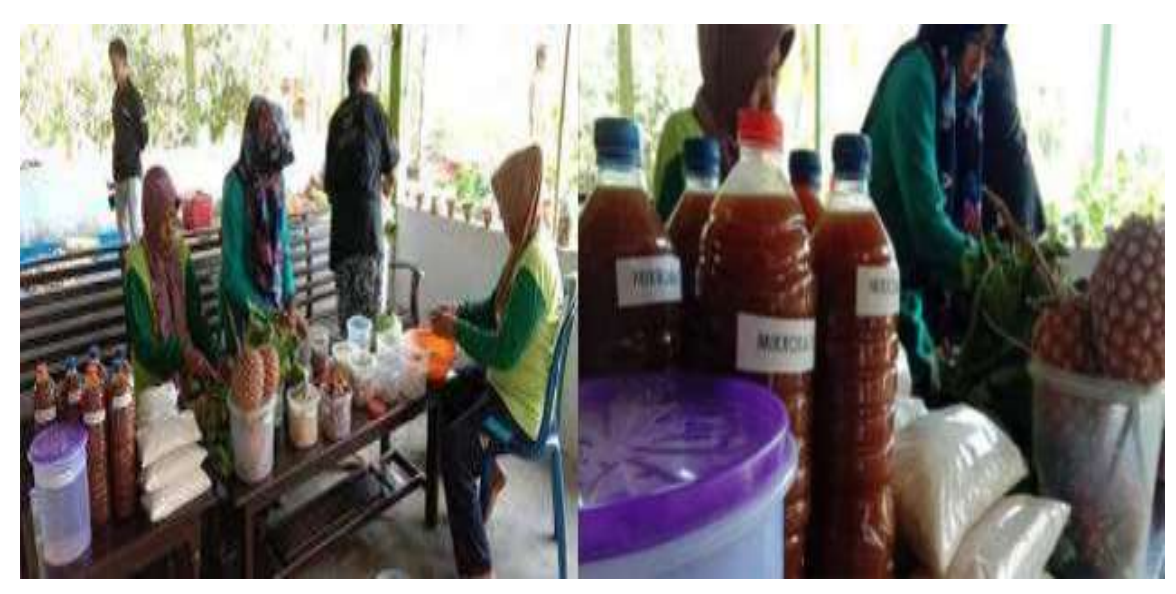

Gambar 1. Pelatihan Pembuatan POC

(CTo Maega / JurnalPengabdian Masyarakat. This is an open access article under the CC BY-SA 4.0 license (https://creativecommons.org/licenses/by-sa/4.0/). 


\subsection{Pelatihan Strategi Pemasaran Produk}

Pelatihan Keterampilan Pemasaran (job training). Melalui kegiatan ini mitra memahami dan megaplikasikan manajemen pemasaran dan strategi yang tepat. Melalui nara sumber Dr. Melati,M.Si dipaparkan model pemasaran yang tepat bagi produk mitra kelompok Rajawali. Pendampingan Pembuatan desain Kemasan. Kegiatan ini berupa pembuatan kemasan produk dari mitra, pendampingan Menjajakan langsung didistributor dan Toko pertanian, Pasar tradisional diwilayah sekitar daerah Konawe Selatan.

\section{Manfaat dari kegiatan pelatihan produksi :}

1. Pengetahuan kelompok pada aspek produksi belum dioptimalkan setelah pendampingan aspek produksi pengetahuan kelompok menjadi optimal

2. Manfaat penyediaan Penampungan pasokan bahan mentah/urin berupa jerigen 1 liter sebanyak 200 buah dirumah warga sekitar mitra. Mitra mampu mengumpulkan bahan baku urin sebanyak 500- 1000 liter urin dari warga.

3. Manfaat diperoleh mitra dengan terbentukknya Unit Pengolahan Pupuk Organik (UPPO) memaksimalkan pengolahn pupuk POC ini.

\section{Manfaat dari kegiatan aspek pemasaran :}

1. Manfaat Pelatihan Keterampilan Pemasaran (job training). Kegiatan ini mitra memahami dan mengaplikasikan manajemen pemasaran dan strategi yang tepat.

2. Manfaat pendampingan. Menjajakan langsung didistributor dan Toko pertanian, Pasar tradisional diwilayah sekitar daerah adalah untuk memperluas jaringan pemasaran produk dimana selama ini produk POC Kelompok Rajawali hanya dikenal disekitar alamat mitra di Konawe Selatan.

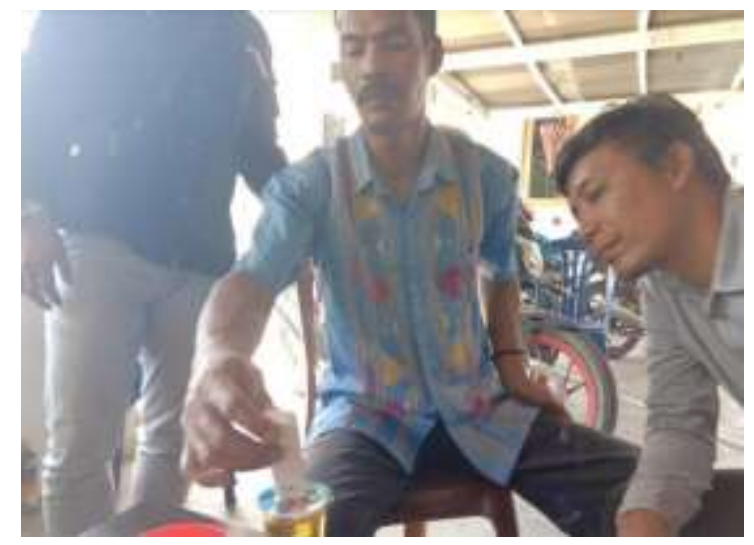

Gambar 2. Pelatihan Pembuatan Pupuk POC

\section{Hasil dan Pembahasan}

Sejalan dengan harapan tim dan mitra dalam kegiatan pengabdian ini maka dampak positif yang terlihat diuraikan sebagai berikut : 


\subsection{Dampak Ekonomi}

Kegiatan yang berjalan beberapa bulan ini sangat berdampak positif khususnya bagi mitra apa lagi kegiatan ini harus diselesiakan secara baik meskipun ditengah pandemic covid 19 di seluruh penjuru dunia tak terkecuali di Indonesia, bahkan ditengah penerapan PSBB di Sulawesi Tenggara yang nota bene merupakan lokasi pelaksanaan kegiatan pengabdian ini tim bersama mitra secara maksimal mampu melaksanakan kegiatan ini. Tim bersyukur kegiatan ini mampu berjalan dengan baik yang juga berdampak positifi bagi mitra. Dapat kami urai sebagai berikut :

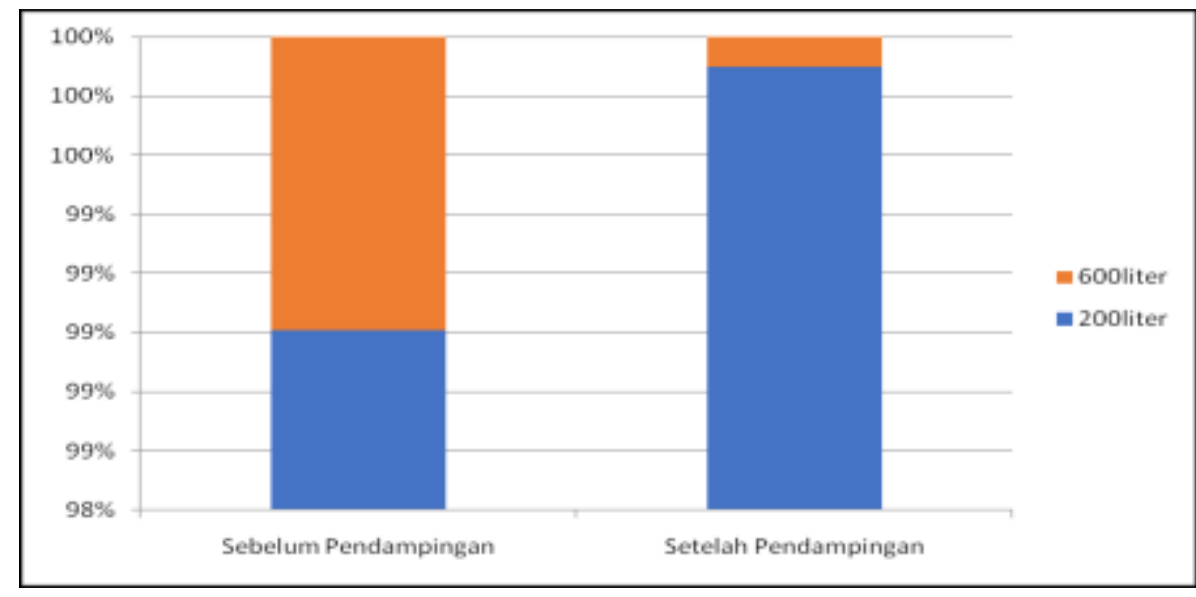

\section{Grafik 3.Kenaikan Pasokan Urin}

Tambahan penyediaan tandon penampungan dan 200 buah wadah penyimpanan kapasitas 1 liter terjadi peningkatan stok urin 200 liter/hari) atau naik 40\% dengan demikian peningkatan Produksi POC 600 liter/6 hari atau naik $25 \%$ dengan demikian maka peningkatan laba 600 liter X Rp.15.000= Rp.9.000.00/6 hari atau naik $25 \%$.

Keuntungan usaha sebelumnya omset penjualan 4-5 Juta/perbulan setelah kegiatan dapat naik menjadi 8juta/perbulan atau dapat naik 100\%. Berikut grafik kenaikan setelah penyedian wadah 1 liter dirumah warga dari awalnya 200 liter/hari menjadi 600 liter/hari.

Keuntungan usaha Kelompok Rajawali sebelumnya omset penjualan 4-5 Juta/perbulan setelah kegiatan dapat naik menjadi 8juta/perbulan atau dapat naik $100 \%$.

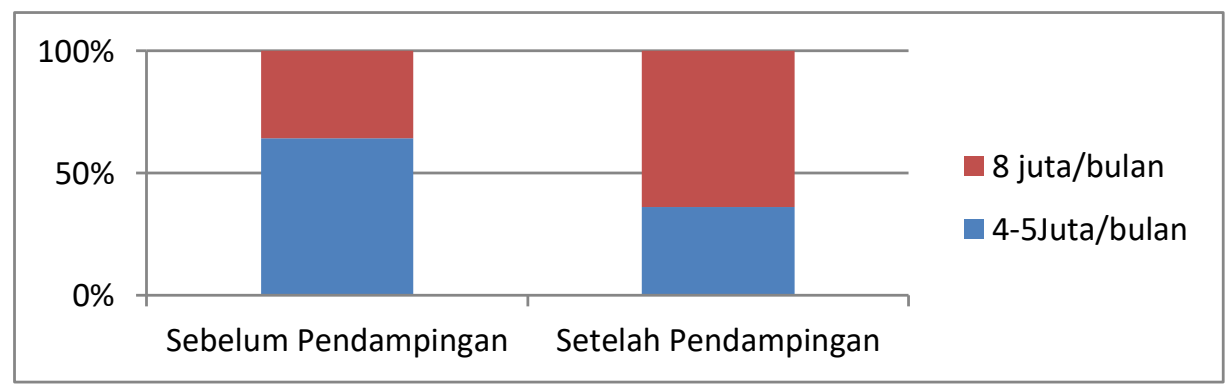

Grafik 4. Kenaikan Keuntungan Usaha 
Pendampingan/memfasilitasi membangun jaringan kerjasama/kemitraan lembaga donator keuangan pengembangan UMKM dalam hal ini Bank Bahteramas Provinsi Sulawesi Tenggara memberi haparan besar bagi bantuan permodalan mitra.

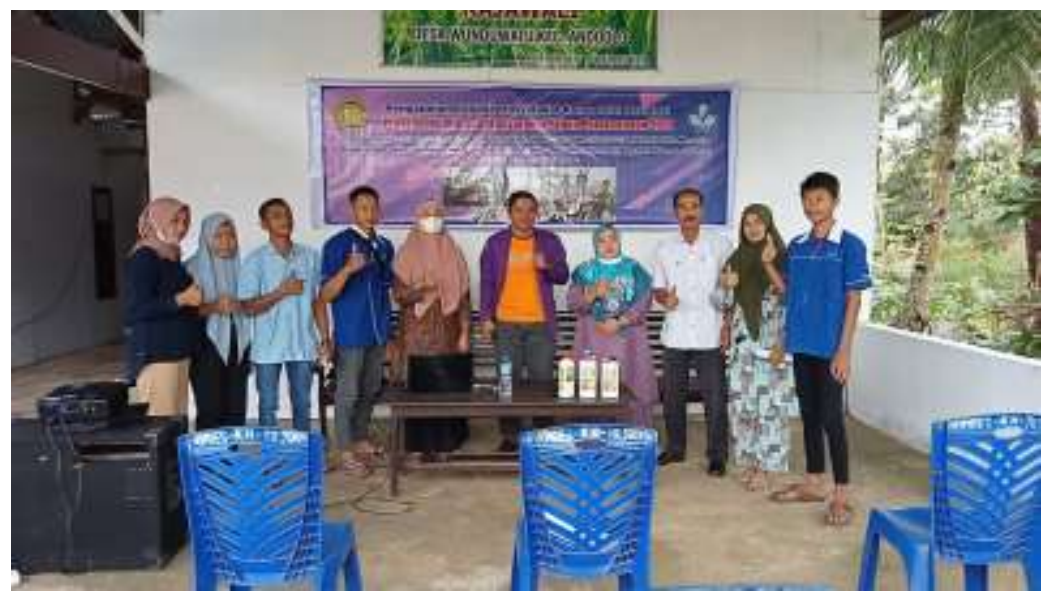

Gambar 5. Pelatihan Pemasaran Produk

\subsection{Dampak Sosial}

Adapun dampak sosial dari pelaksanaan kegiatan pengabdian pada kelompok Rajawali ini diuraikan sebagai berikut melalui kegiatan pengabdian pada kelompok Rajawali ini maka mitra dapat mengurangi pengangguran disekitar lokasi mitra dimana kebanyakkan dari mereka adalah para ibu rumah tangga, saat ini ada 7 orang pekerja baru tambahan. Berikut tampilan grafik :

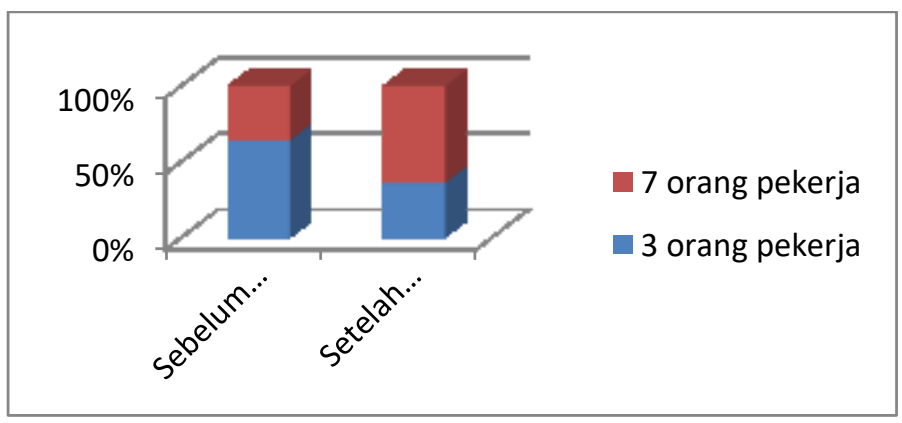

Grafik 6. Kenaikan Jumlah Pekerja

Usaha produksi POC basis urin kelompok Rajawali ini juga telah menarik minat kelompok usaha sekitar melihat potensi ekonomi yang dihasilkan sangat menjanjikan mampu menghidupi perekonomian masyarakat seperti halnya kelompok Rajawali di pimpin oleh Pak Rohsidin. Berikut grafik minat masayarakat sekitar : 


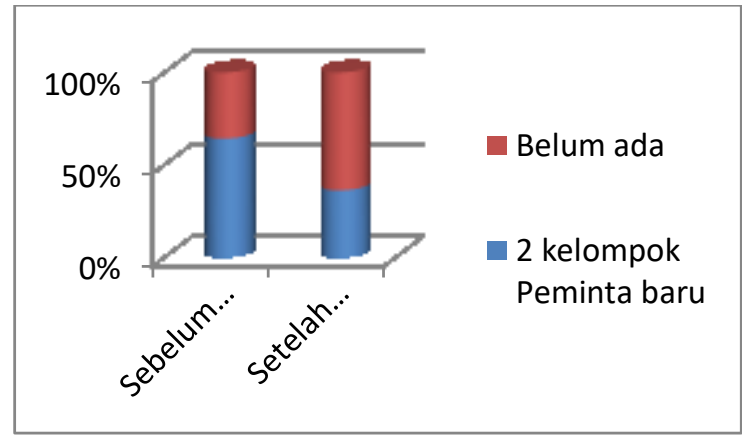

Grafik 7. Kenaikan Minat Masyarakat Desa Wunduwatu

\section{Kesimpulan}

Tim berkesimpulan dalam pelaksanaan kegiatan pendampingan pembuatan pupuk organic cair (POC) basis urin pada kelompok Rajawali Desa Wunduwuta Kabupaten Konawe Selatan ini yaitu kegiatan pendampingan pelatihan produksi kelompok Rajawali mampu meningkatkan jumlah produksi olahan POC POC 600 liter/6hari yang sebelumnya hanya 200liter/minggu. Hasil kegiatan pendampingan pada pelatihan strategi pemasaran kelompok Rajawali keuntungan dari usaha yang awalnya omset usaha ini 4-5 juta/bulan setelah kegiatan pendampingan omset usaha ini mampu meningkatkan 8 juta/bulan. Kegiatan pendampingan ini mampu mengurangi jumlah pengangguran disekitar lokasi mitra dimana saat ini seiring bertambahnya keuntungan usaha maka pihak mitra mampu menyerap pekerja baru khsusunya dari kalangan ibu rumah tangga.

Sejalan dengan kesimpulan maka beberapa saran yang patut disampaikan terkait pelaksanaan kegiatan pendampingan ini diantaranya Pemerintah daerah perlu memfasilitasi kegiatan usaha ini terutama dari aspek permodalan usaha dan salah satu kendala utama yang dihadapi oleh mitra (Kelompok Rajawali) adalah belum adanya merk resmi produk yang dihasilkan (POC) sehingga sulit melakukan pemasaran secara komersil, proses pengurusan merk ini memerlukan biaya yang sangat besar dimana sebelum mendaftarkan merk produk POC ini perlu dilakukan uji kandungan produk dilaboratorium, selanjutnya pemerintah daerah perlu pula membantu usaha kelompok Rajawali ini dalam rangka sosialisasi produk POC ini oleh karena masih kurangnya pengetahuan calon konsumen akan keuntungan efektifitas menggunakan produk tersebut yang menimbulkan keraguan ditengah masyarakat produk yang murah, aman bagi lingkungan yang sampai saat ini masih memilih produk pupuk komersial yang terbukti banyak merusak ekologi pertanian petani. 


\section{Ucapan Terimakasih}

1. Direktorat Riset dan Pengabdian Masyarakat Direktorat Jenderal Riset dan Pengembangan Kementerian Riset, Teknologi, dan Pendidikan Tinggi atas pendanaan Pengabdian Kepada Masyarakat Kompetitif Nasional Skema Program Kemitraan Masyarakat Tahun 2020 Rencana Pelaksanaan PPM: tahun 2021 s.d. tahun 2021

2. Prof. Dr. Hj. Rostin,S.E,M.Si Selaku Rektor Universitas Lakidende yang selalu memberikan dorongan motivasi dalam melaksanakan kegiatan ini

3. Milyan,S.Sos.,M.Si selaku Ketua LPPM Universitas Lakidende atas segala arahan dan bimbingan selama pelaksanaan kegiatan berlangsung

4. Bapak Rosidin Selaku Ketua beserta anggota Kelompok Rajawali Desa Wunduwatu Kecamatan Andoolo Kabupaten Konawe Selatan atas kesediaannya dan peran sertanya sebagai mitra dalam kegiatan ini

5. Kepada seluruh tim yang telah turut berperan aktif dalam pelaksanaan kegiatan ini baik itu anggota tim, tim pembantu lapangan, bagian secretariat/administrasi serta yang tidak dapat kami sebutkan satu persatu

\section{Daftar Pustaka}

Ari, S. (2004). Teori Ekonomi Mikro, edisi 4, Yogyakarta : BPFE UGM.

Apriyani, N., dan Muhsin, A. (2017). Analisis Pengendalian Persediaan bahan Baku dengan Metode Econimic Order Quantity dan Kanban pada PT. Adyawinsa Stamping Industries. Jurnal OPSI Vol 10 No 2. Yogyakarta

Assauri, S. (2008). Manajemen produksi dan operasi. Jakarta : Lembaga Penerbit Fakultas Ekonomi Universitas Indonesia.

Basu, S., \& Irawan, (2006), Manajemen Pemasaran Modern, Liberty,.Yogyakarta

David, F. R. (2009). Manajemen Strategis Konsep, Edisi 12. Jakarta : Salemba Empat

Didiharyono, D. (2016). Penerapan Metode Statistical Processing Control Untuk Menganalisis Pengendalian Kualitas Produk pada PT. Asera Tirta Posidonia. Jurnal Equilibrium 2 (4), 325-332.

Dinas Pertanian Tanaman Pangan Provinsi Bali. (2013). Laporan Subsidi Pupuk Organik Provinsi Bali.

Fitriana, S. dkk. (2017). IbM Pemanfaatan Tinja Menjadi Pupuk Cair Organik di Kelurahan Tambakrejo. E-dimas education. Pengabdian Kepada Masyarakat

Handoko, T. H. (2000). Dasar-dasar Manajemen Produksi dan Operasi, Edisi pertama. Yogyakarta: BPFE Universitas Gajah Mada

Iriyadi dan Vimiyati, K. (2013). Penerapan Modul Inventory dalam Penyajian Laporan Persediaan Bahan Baku. Jurnal Inventory Modul Implementation. Bogor: Sekolah Tinggi Ilmu Ekonomi Kesatuan

Irwan, I., \& Haryono, D. (2015). Pengendalian Kualitas Statistik (Pendekatan Teoritis dan Aplikatif). Bandung Alfabeta

Indriyo, G. (2008). Manajemen Pemasaran. Edisi kedua, Yogyakarta: BPFE 
Kamil. M. (2012). Model Pendidikan dan Pelatihan (Konsep dan Aplikasi). Bandung: Alfabeta.

Kotler, P. (2000). Manajemen Pemasaran. Edisi Mileinium. Jakarta : PT. Indeks Kelompok Gramedia.

Lestari, W. dkk. (2015). Respon Pemberian Pupuk Organik Cair (POC) Limbah Sayur terhadap Pertumbuhan dan Produksi Tanaman Tomat (Lycopersicum esculentum. L). Jurnal Agroplasma (STIPER) Labuhan batu Vol 2 N0 1 Mei 2015

Marzuki, S. H.M. (2010). Pendidikan Nonformal. Dimensi Fungsional, Pelatihan, dan Andragogi. Bandung: Penerbit Rosda.

Musnamar, E. I., (2009). Pupuk Organik: Cair dan Padat, Pembuatan, Aplikasi. Jakarta: Penebar Swadaya

Novizan, (2007). Petunjuk Pemupukan Yang Efektif. Jakarta: Agromedia Pustaka.

Shella. (2012). Kajian Pemberian Pupuk Hijau Eceng Gondok pada Tanah Gambut Terhadap Pertumbuhan Vegetatif Tanaman Terong (Solanummelongena L.), Jurnal Anterior. 11 (1).

Sudarman, dan Sunyoto. (2016). IbM Kelompok Usaha Tani dan Peternakan. Rekayasa Vol 14 No 1 Juli 2016

Sutejo, M. (2002). Pupuk dan Cara Pemupukan. Jakarta: Rineka Cipta. 